\title{
$25^{1 \mathrm{~m}}{ }_{\text {ANNIVERSARY }}$
}

\section{Bird Conservation International}

journals.cambridge.org/bci

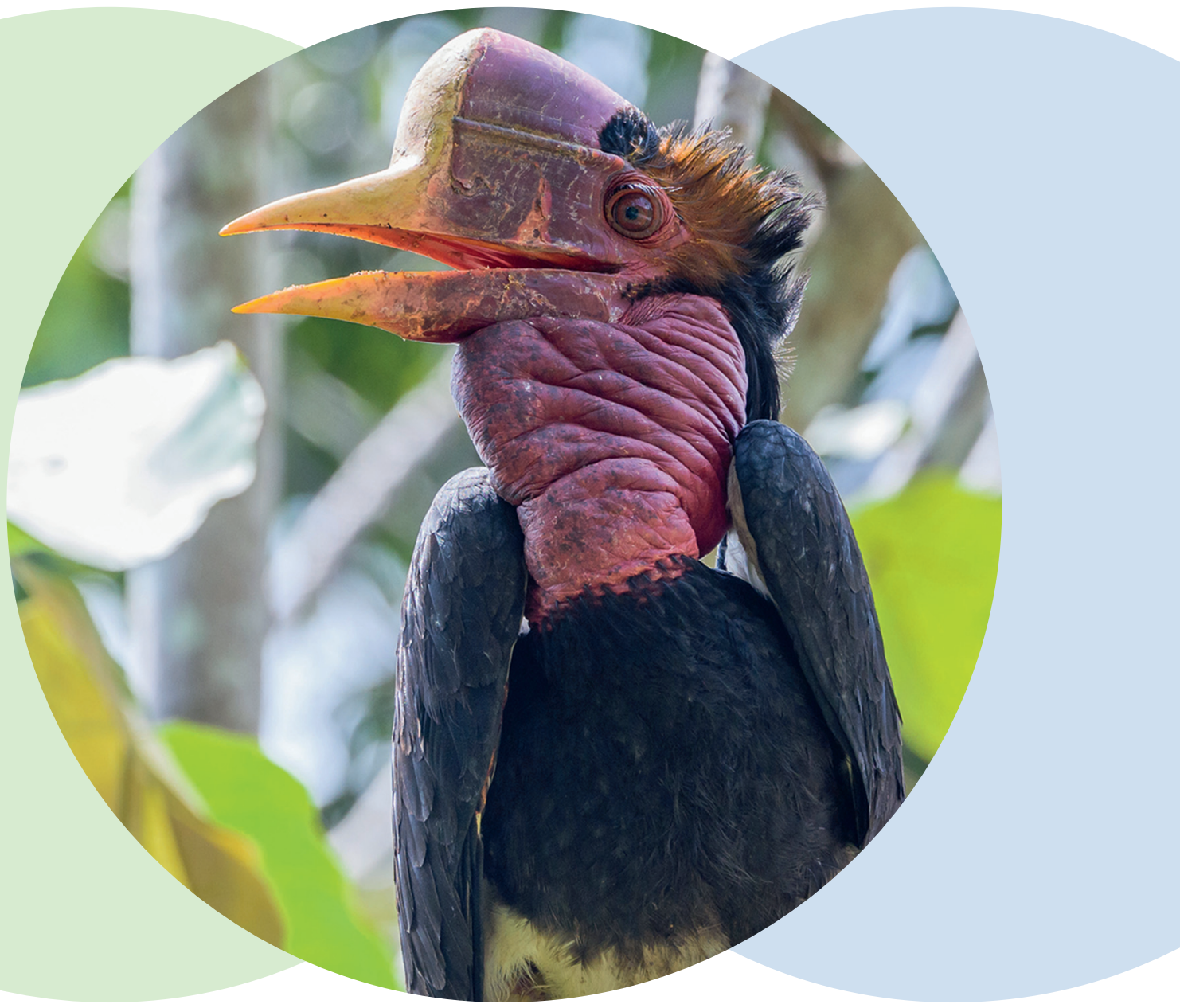

)2 


\section{Bird Conservation International}

Editor in Chief: Dr Phil Atkinson, British Trust for Ornithology, The Nunnery, Thetford, IP24 2PU, UK email bcieditor@bto.org

Consulting Editor: N. J. Collar

Associate Editors:

Dr Mattia Brambilla, Italy

Dr Tom Brooks, Switzerland

Dr Graeme Buchanan, UK

Dr Edwin Harris, UK

Dr Margaret Kinnaird, USA

Professor Zhijun Ma, China

Professor Lei Cao, China

Dr Antoni Margalida, Spain

Dr Pedro Ferreira Develey, Brazil

Dr Tim Dodman, UK

Dr Paul Donald, UK

Dr Juan Carlos Reboreda, Argentina

Dr Peter Ryan, South Africa

Dr Judit Szabo, Republic of Korea

Professor Stephen Garnett, Australia

Dr José Tella, Spain

Dr Rhys Green, UK

Dr Pablo Yorio, Argentina

(C) BirdLife International 2016

Subscriptions: Bird Conservation International (ISSN: 0959-2709) is published quarterly in March, June, September and December in which four parts form a volume, by Cambridge University Press, Journals Fulfillment Department, UPH, Shaftesbury Road, Cambridge CB2 8BS, UK. /Cambridge University Press, 32 Avenue of the Americas, New York, NY 10013, USA. The subscription price (excluding VAT) of Volume 26, 2016, which includes print and electronic access, is $£ 349$ (US $\$ 654$ in the USA, Canada and Mexico) for institutions; $£ 113$ (US $\$ 210$ in the USA, Canada and Mexico) for individuals, which includes print only. The electronic-only price available to institutional subscribers is $£ 280$ (US \$529 in the USA, Canada and Mexico). Single parts cost $£ 97$ (US \$183 in the USA, Canada and Mexico) plus postage. EU subscribers (outside the UK) who are not registered for VAT should add VAT at their country's rate. VAT registered subscribers should provide their VAT registration number. Japanese prices for institutions are available from Kinokuniya Company Ltd, P.O. Box 55, Chitose, Tokyo 156, Japan. Prices include delivery by air. Orders, which must be accompanied by payment, may be sent to any bookseller, subscription agent or direct to the publisher: Cambridge University Press, Journals Fulfillment Department, UPH, Shaftesbury Road, Cambridge CB2 8BS, UK. ; or in the USA, Canada and Mexico; Cambridge University Press, 32 Avenue of the Americas, New York, NY 10013, USA. Periodical postage paid at New York, NY and additional mailing offices.

Postmaster: send address changes in USA and Canada to: Bird Conservation International, Cambridge University Press, 32 Avenue of the Americas, New York, NY 10013, USA.

Claims for missing issues should be made immediately on receipt of the subsequent issue.

Bird Conservation International is included in the Cambridge Journals Online service which can be found at http://journals.cambridge.org/. For further information on other Press titles access cambridge.org/.

Copying: This journal is registered with the Copyright Clearance Center, 222 Rosewood Drive, Danvers, MA 01923, USA. Organizations in the USA who are also registered with the C.C.C. may therefore copy material (beyond the limits permitted by sections 107 and 108 of US copyright law) subject to payment to C.C.C. of the per-copy fee of $\$ 16$. This consent does not extend to multiple copying for promotional or commercial purposes. Code 0959-2709/2016 \$16.

ISI Tear Sheet Service, 3501 Market Street, Philadelphia, Pennsylvania 19104, USA, is authorized to supply single copies of separate articles for private use only.

Organizations authorized by the Copyright Licensing Agency may also copy material subject to the usual conditions. For all other use, permission should be sought from Cambridge or the American branch of Cambridge University Press.

Cover photograph: The Helmeted Hornbill has been listed in Appendix of CITES since 1975 and the trade in the species is not permitted. In 2015, partly in response to the evidence in the paper authored by Claire Beastall et al. in this issue, its IUCN Red List status was uplifted from 'Near Threatened' to 'Critically Endangered', justified by the expectation that populations will experience an extremely rapid and severe decline over the next three generations. Poaching and illegal trade were listed as leading threats. The study published in this volume compiled data on recent seizures of Helmeted Hornbills, or their body parts, in order to make a first assessment of the numbers currently occurring in the illegal trade across Asia and to assist in guiding future conservation and enforcement efforts. Image credit: Muhammad Alzahri.

\section{Cambridge University Press}

Journals Fulfillment Department, UPH, Shaftesbury Road, Cambridge CB2 8BS, UK.

32 Avenue of the Americas, New York, NY 10013-2473, USA

477 Williamstown Road, Port Melbourne, VIC 3207, Australia

Ruiz de Alarcón 13, 28014 Madrid, Spain

Dock House, The Waterfront, Cape Town 8001, South Africa 